\title{
Uniwersalność przestrzeni i obiektów użyteczności publicznej w kontekście osób z dysfunkcją wzroku
}

\author{
Elżbieta Przesmycka, Wojciech Jabłoński, Joanna Kania
}

Zakład Konstrukcji i Budownictwa Ogólnego, Wydział Architektury, Politechnika Wrocławska

\begin{abstract}
Streszczenie: Bardzo często niepełnosprawność kojarzona jest z dysfunkcjami motorycznymi, podczas gdy dysfunkcje wzroku, słuchu czy psychologiczne nie są zakorzenione w świadomości ogółu społeczeństwa. Jednak podobnie jak zaburzenia ruchowe, zaburzenia wzroku są naturalnym etapem procesu starzenia się. Brak dostosowania przestrzeni i obiektów użyteczności publicznej dla osób niewidzących lub słabowidzących stanowi więc często barierę dla osób z wadami wzroku oraz osób starszych. W artykule przedstawiono sposoby mające na celu udogodnienie osobom niepełnosprawnym korzystania z obiektów i przestrzeni publicznych. Artykuł podzielony został na dwie części. Pierwsza obejmuje działania architektoniczno-budowlane - wskazując podstawowe zasady w kształtowaniu architektury oraz wskazując na niektóre błędy pojawiające się w obiektach budowlanych, które mogą zagrażać życiu, bezpieczeństwu lub komfortowi psychicznemu osób z dysfunkcjami wzroku. Rozwiązania architektoniczne mogą stanowić ułatwienie orientacji w przestrzeni czy odbioru bodźców środowiska architektonicznego, ale nie zawsze system informacji szczegółowej. Druga część artykułu poświęcona jest technikom tyflograficznym mogącym znaleźć zastosowanie w przestrzeniach publicznych jako formy małej architektury lub detalu - uzupełnienia architektury. Rozwiązania te wskazują na dokładniejsze informacje, takie jak system komunikacji w obiekcie, czy informacji użytkowych. Obie części artykułu wskazują na rozwiązania architektoniczne oraz ogólnie rozumianego designu mające na celu umożliwienie sprawnego i bezpiecznego funkcjonowania w obiekcie. Wskazują również na fakt, że projektowanie z uwzględnieniem osób z dysfunkcjami wzroku powinno zaczynać się już na etapie koncepcji funkcjonalno-przestrzennej, a obejmować także detal oraz rozwiązania w fazie wykonawczej oraz fazę życia obiektu przez właściwe zarządzenie przestrzenią.
\end{abstract}

Słowa kluczowe: projektowanie uniwersalne, dysfunkcje wzroku, obiekty użyteczności publicznej

\section{Wstęp}

Większość ogólnych i szczegółowych informacji, docierających do odbiorcy z otoczenia, jest odbieranych przez wzrok. Świat postrzegany w ten sposób wydaje się prosty, i wręcz oczywisty, ponieważ nie wymaga od użytkownika ciągłego skupienia na odbieraniu istotnych bodźców, takich jak orientacja w przestrzeni. Wiele codziennych czynności odbywa się w chaotycznym środowisku miasta. Podróże, służba zdrowia, nauka, kultura wyższa, sprawy urzędowe czy zwykły handel to tylko niektóre zagadnienia towarzyszące życiu codziennemu. Wiele z tych miejsc charakteryzuje się dużym natężeniem użytkowników, co wywołuje ciągłe zmiany danej przestrzeni. Wymaga to często wzmożonej uwagi odbiorców, nawet tych, którzy są w pełni sprawni, zarówno fizycznie jak i umysłowo. Źle zaprojektowane otoczenie może stanowić rodzaj bariery dla osób niepełnosprawnych będąc przestrzenią o nieprawidłowym systemie informacji o środowisku fizycznym. Zagrożeniem w tym wypadku może być zarówno niedobór jak i nadmiar bodźców. Każdy bodziec to informacja lub dezinformacja, które wprowadzają odbiorcę w określony stan, część z nich będzie wywoływała dyskomfort psychiczny lub wymagała wzmożonego skupienia. Nieprzyjazne środowisko fizyczne wpływa nie tylko na bezpieczeństwo i komfort samego użytkowania danej przestrzeni, ale również na ogólne samopoczucie osób z dysfunkcjami, zniechęcając ich do uczestnictwa w życiu społecznym i tym samym powodując ich dalszą alienację od życia społecznego.

Bardzo często osoby niepełnosprawne kojarzy się wyłącznie z dysfunkcjami motorycznymi, podczas gdy pozostałe schorzenia takie jak wzrokowe, słuchowe czy psychologiczne pozostają w mniejszej świadomości 
społeczeństwa. Według danych GUS-u na rok $2014^{1}$ prawne orzeczenie o niepełnosprawności posiadało 3,8 miliona mieszkańców Polski, przy jednoczesnym wskazaniu, że dysfunkcje wzroku występowały u około 35\%-. Obejmują one nie tylko całkowity brak zdolności widzenia, ale również częściową utratę wzroku oraz zaburzenia: utratę widzenia pola centralnego lub bocznego, utratę widzenia kontrastów, problemy z oceną odległości, ostrością widzenia, zaburzenia widzenia kolorów. W kontekście starzejącego się społeczeństwa problem wydaje się jeszcze szerszy, gdyż obok ograniczonej sprawności motorycznej schorzenia wzroku są najczęściej występującym problemem wśród seniorów. Czynnikiem wpływającym na ilość osób z zaburzeniami wzroku są również zmiany społeczne, czyli przekształcenie się społeczeństwa na społeczeństwo informacyjne, którego praca opiera się głównie na sektorze usług, tym samym warunkując konieczność pracy przy monitorach. Wymaga to ciągłego wytężania pracy oczu, którym nie pozwala się wypocząć nawet po godzinach, gdyż najczęstszym sposobem spędzania wolnego czasu są ekrany komputerów i telewizorów. Zmiany społeczne nie są głównym czynnikiem wpływającym na kształtowanie przestrzeni publicznej pod kątem osób niepełnosprawnych, ale wskazują one na rozwijający się problem ilości osób z wadami lub zaburzeniami widzenia.

Różnorodność problemów związanych z dysfunkcjami wzroku warunkuje konieczność stosowania - wielu rozwiązań architektonicznych i budowlanych mających na celu poprawę jakości funkcjonowania osób niewidzących oraz słabowidzących w życiu społecznym w sposób pełny i bezpieczny zgodnie z przyjętymi rezolucjami i rozporządzeniami gwarantującymi osobom niepełnosprawnym możliwości korzystania z przestrzeni oraz funkcji publicznych. Przestrzeń publiczna już z definicji zakłada, że powinna być dostępna dla każdej jednostki -, umożliwiając jej realizację potrzeb społecznych. W kontekście osób niepełnosprawnych wymogi te dotyczą również innych rodzajów przestrzeni - takich jak takich jak przestrzenie półpubliczne i półprywatne, rozumiane tu głównie przez usługi, handel czy gastronomię. Bariera, jaką jest często nieświadomie zaprojektowana forma architektoniczna czy środowisko kulturowe, stanowi dyskryminację takich osób z życia społecznego. Często obiekty użyteczności publicznej stanowią skomplikowane układy, dostarczając ogromną ilość informacji służącą skutecznemu ich użytkowaniu. Dotyczą one zarówno układu funkcjonalno-przestrzennego samych obiektów, jak i informacji użytkowych, związanych z przemieszczaniem się czy turystyką.

Do odbioru wzrokowego potrzebne są następujące elementy: bodziec składający się z światła padającego na obiekt oraz receptor czyli oko, z którego informacja za pomocą układu nerwowego przesyłana jest do mózgu. O ile medycyna może ograniczyć problemy związane z odbiorem obrazu, receptorem oraz mózgiem, o tyle architektura, inżynieria oraz ogólnie rozumiany design może wpływać na kształtowanie środowiska fizycznego oraz na sam obiekt użytkowy, poprawiając jego odbiór percepcyjny. Poprzez odpowiednie kształtowanie środowiska życia i jego poszczególnych elementów można ułatwić proces postrzegania zarówno wzrokowego jak i pozawzrokowego.

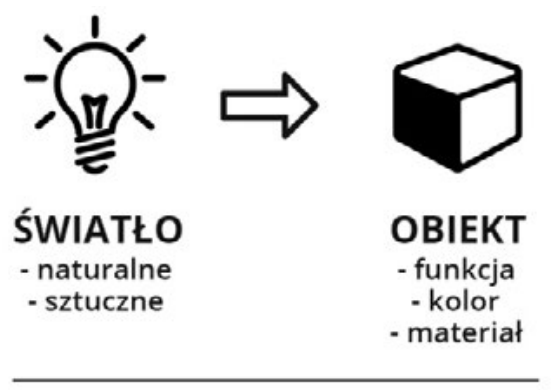

\section{Architektura \\ Design Inżynieria}

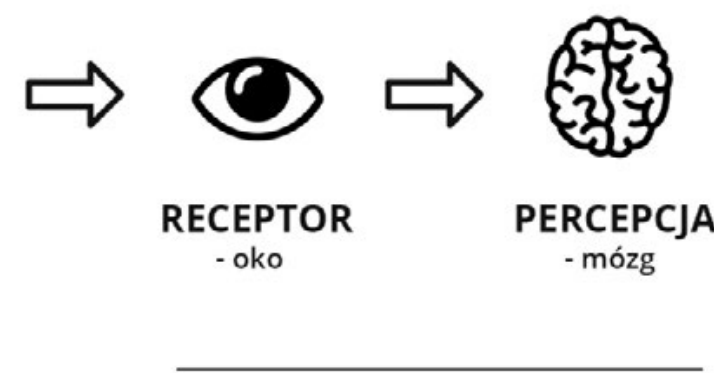

Medycyna

Ryc. 1. Schemat odbioru informacji wzrokowej (oprac. J.Kania)

Ryc.1. Scheme of visual perception, oprac. J. Kania) 


\section{Światło}

Światło naturalne i sztuczne bardzo często jest wykorzystywane - do kreowania odbioru obiektu architektonicznego. Gra światłem i cieniem ma za zadanie wywołać odpowiednie nastroje we wnętrzach oraz budować dynamikę bryły. Pojedyncze perforacje w ścianach tworzą interesujące mozaiki świetlne. Gęste wertykalne podziały szklanej elewacji tworzą monumentalny charakter obiektu, jednak we wnętrzu powstają wtedy mocne plamy światła i pola o intensywnej zmianie natężenia oświetlenia. Wpływa to niekorzystnie na percepcję wzrokową użytkowników, a w szczególności niepełnosprawnych z dysfunkcjami widzenia. Problem ten dotyka nie tylko osób mających trudności z adaptacją oka, ale także słabowidzących lub będących w fazie widzenia światła (brak widoczności kolorów, kształty w sposób ograniczony widoczne przez różnice w natężeniu światła). Równomiernie oświetlone, jasne wnętrza pomagają widzieć kształty i kolory - podstawowe informacje o środowisku fizycznym oraz ułatwiają odczytanie informacji szczegółowych dotyczących poszczególnych celów użytkowych danej przestrzeni.

Wielokrotnie można spotkać się z wnętrzami architektonicznymi o nierównomiernym oświetleniu. Dotyczy to zarówno pojedynczych stref funkcjonalnych, takich jak komunikacja oraz przejść pomiędzy dwiema strefami, np. komunikacją a biurem. Długie i często szerokie, ciągi komunikacyjne takie jak korytarze czy hole w obiektach użyteczności publicznej posiadają tylko fragmentaryczne doświetlenie światłem naturalnym, często o orientacji nastawionej na intensywne doświetlenie w ciągu dnia. Powstają w ten sposób strefy funkcjonalne, w których występują podstrefy jasne i ciemne z mocno naznaczoną granicą pomiędzy nimi, niosąc za sobą dwa zagrożenia związane głównie z akomodacją oka. Pierwszym zagrożeniem jest przejście użytkownika pomiędzy dwiema podstrefami, gdy oko jest nieprzyzwyczajone do natężenia światła. Jasna strefa funkcjonalna będzie wtedy wydawała się jaśniejsza, a ciemna jeszcze ciemniejsza, powodując tym samym chwilowe oślepienie użytkownika, które w przypadku osób z dysfunkcją wzroku może być bardziej uciążliwe. Tworzenie się podstref jasnych i ciemnych wpływa też na odbiór całego układu architektonicznego, gdzie poszczególne elementy są słabo widoczne, wpływając tym samym niekorzystnie na percepcję tej przestrzeni, w której część informacji należącej do tej samej strefy funkcjonalnej jest nieczytelna lub niepełna. Problem nierównomiernego oświetlenia dotyczy również dwóch stref funkcjonalnych. Przejścia pomiędzy strefami jasną a ciemną bardzo często spotykane są w konwencjonalnych przestrzeniach biurowych z pomieszczeniami wymagającymi odpowiedniego doświetlenia oraz izolacji od przestrzeni komunikacji. Z tego powodu ciągi komunikacyjne często pozbawione są oświetlenia naturalnego, co uzupełnia się światłem sztucznym. Przejście użytkownika pomiędzy pomieszczeniami może powodować wcześniej wspomniane oślepienie związane ze zmianą natężenia światła.

Innym problemem nierównomiernego doświetlenia światłem naturalnym jest kształtowanie perforacji okiennych jako formy wyrazu architektonicznego. Liczne, drobne punkty na elewacji mogą budować nie tylko dynamikę na elewacji, ale również bardzo ekspresyjne doświetlenie wnętrza, w którym powstają pojedyncze plamy świetlne, zaburzające odbiór przestrzeni. Polskie przepisy dotyczące doświetlenia nie określają kształtów stolarki, ani ich rozmieszczenia, a jedynie sumaryczną powierzchnię doświetlającą względem powierzchni pomieszczeń ${ }^{2}$. Powstaje $w$ ten sposób zagrożenie w postaci pojedynczych promieni świetlnych o różnym stopniu natężenia światła, - które mogą tymczasowo oślepiać. Chwilowe oślepienie w takim wypadku stwarza zagrożenie fizyczne pomiędzy użytkownikami, jak i w relacjach między użytkownikiem a obiektem.

Popularną metodą na kontrolowanie natężenia światła we wnętrzach obiektów architektonicznych jest stosowanie różnego rodzaju żaluzji stałych lub ruchomych oraz dodatkowych elementów w szkle, mających za zadanie zmniejszenie ilości światła w wnętrzu, np. ogniw fotowoltaicznych mono-i polikrystalicznych. Powstałe w ten sposób ograniczenia dostępu światła tworzą gęsto występujące pola światła i cienia o relatywnie małych polach powierzchni. Nierzadko taka gra światła i cienia jest zagrożeniem nie tyle w odbiorze, co interpretacji danych bodźców przez ośrodek w mózgu. Wskazuje to, że problem może dotykać nie tylko osób niepełnosprawnych wzrokowo, ale też osób z dobrze funkcjonującym wzrokiem Tego typu zagrożenie jest szczególnie wyraźne w kontekście przestrzeni komunikacyjnych takich jak hole wejściowe czy klatki schodowe, w których to szczególnie ważna jest właściwa interpretacja elementów budowlanych ze względu na bezpieczeństwo 
zdrowia tudzież w miejscach pracy, gdzie głębokie różnice między światłem a cieniem mogą znacząco utrudnić odczytywanie informacji.
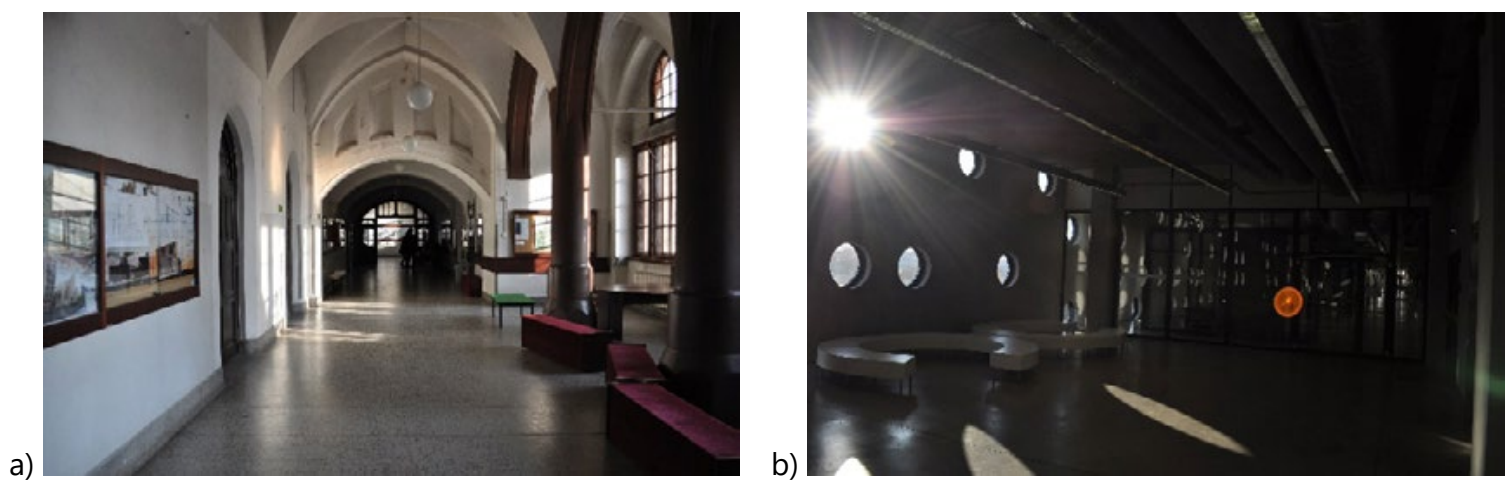

Ryc. 2. Światło w przestrzeniach publicznych: A - Politechnika Wrocławska E-1, podstrefy jasne oraz ciemne w przestrzeni jednej funkcji, fot. W. Jabłoński; B - Politechnika Wrocławska C-13, punktowe nierównomierne oświetlenie naturalne, fot. W. Jabłoński;

II. 2. Natural light in public utility buildings: A - Wrocław University of Science and Technology E-1, light and dark subzones in single functional area; B - Wrocław University of Science and Technology C-13, points of natural lighting; phot. W. Jabłoński

Podobnie jak światło naturalne, również światło sztuczne może kreować odbiór przestrzeni i nastrój wnętrz. Świadome kształtowanie iluminacji obiektów wspomaga ich odbiór, jednak niewłaściwie skierowane lub nierównomierne światło może zaburzyć odbiór przestrzeni i spowodować zagrożenia dla bezpieczeństwa i zdrowia użytkowników. Chaotyczne oświetlenie, szczególnie odczuwalne w przestrzeniach miejskich, niesie za sobą zagrożenie dezinformacji lub nadmiernej ilości informacji, często mało istotnych z punktu widzenia podstawowych funkcji użyteczności publicznych. W wnętrzach architektonicznych w celu poprawy odbioru należy stosować zrównoważone oświetlenie stref funkcjonalnych. Równomierność doświetlenia dotyczy również stosowanego rodzaju światła i jego położenia. Punktowe źródło światło, zwłaszcza nieosłonięte, może powodować efekt olśnienia ze względów na problemy z akomodacją oka. Ponadto światło sztuczne winno podkreślać najważniejsze informacje w przestrzeni, takie jak powierzchnie poszczególnych przegród czy poszczególne systemy informacji, np. numery i oznaczenia pomieszczeń, rozkłady jazdy.

\section{Obiekt - rozwiązania architektoniczno-budowlane}

Drugim elementem składającym się na bodziec wzrokowy jest sam obiekt widziany. Jest on o tyle ważny, że jego właściwe ukształtowanie może wpływać korzystnie zarówno na osoby słabo widzące, jak i niewidzące.

W kontekście projektowania uniwersalnego niezwykle ważny jest właściwy rozkład obiektu. Skomplikowane układy funkcjonalne bywają trudne do odczytania nawet dla użytkowników w pełni sprawnych fizycznie czy umysłowo. Osoby pełnosprawne wzrokowo, orientując się w przestrzeni, polegają przede wszystkim na zmyśle wzroku, na którym oparta jest dominująca część informacji w obiektach. Dla osób z dysfunkcją wzroku schemat funkcji i właściwe ich ułożenie może stanowić źródło informacji o poszczególnych strefach w obiekcie. Utworzenie elementów zgrupowanych w jedną komórkę funkcjonalną występującą w sposób powtarzalny pozwala na odpowiednią orientację w przestrzeni, w której jeden element wskazuje na występowanie drugiego. Przykładem tego typu komórek funkcjonalnych może być zestawienie trzech elementów takich jak bankomat, blok toalet i pion komunikacyjny. Powtarzalność tego zestawienia w obiekcie tworzy informację o występowaniu jednej funkcji względem drugiej. Owe zestawienia mogą dodatkowo zostać podkreślone poprzez mało inwazyjne zmiany przestrzenne, takie jak cofnięcie komórki względem ciągu funkcjonalnego lub poprzez wprowadzenie dodatkowej informacji odbieranej przez inne zmysły, takiej jak fontanna (oddziaływanie na słuch i zmianę temperatur) lub kwietnik (oddziaływanie na zmysł węchu). 
W wielofunkcjonalnych obiektach takie jak centra handlowo-usługowe czy węzły przesiadkowe - zaciera się granica pomiędzy poszczególnymi strefami funkcjonalnymi. Na dworcach pasażerskich strefy komercyjne wnikają w tkankę komunikacyjną, utrudniając tym samym właściwą identyfikację przestrzenną. Lokale gastronomiczne i handlowe stanowią bardzo ważną funkcję uzupełniającą dworca, jednak bardzo często dominują nad przestrzeniami komunikacji pasażerskiej, budując tym samym mylne wrażenie dotyczące samego obiektu. Przykładem zatartej granicy między handlem a transportem jest Dworzec Kraków Główny (il. 3). Obiekt jest połączony z Galerią Krakowską, która jednocześnie stanowi wejście w przestrzeń dworca oraz wyjście w kierunku centrum miasta. Głównym elementem jest tzw. hol dworcowy, który de facto jest tunelem łączącym dworzec autobusowy z galerią handlową. Dominującą funkcją znajdującą się w owym pasażu są lokale gastronomiczne oraz handlowe, uzupełnione o wyjścia na perony. Fragment holu, przy którym znajdują się najważniejsze funkcje dotyczące podróży, znajduje się na marginesie głównego ciągu komunikacyjnego, a dodatkowo jest fizycznie oddzielony różnicą wysokości i lokalami komercyjnymi. Z tej części dostęp na perony jest ograniczony co wymusza na użytkownikach powrót do chaotycznej przestrzeni komercyjno-podróżnej. Użytkownik w środowisku fizycznym nowego dworca w Krakowie znajduje się w przestrzeni o nieokreślonej funkcji - ciąg komunikacyjny stanowi bardziej przedłużenie pasażu handlowego niż obiekt transportu pasażerskiego.

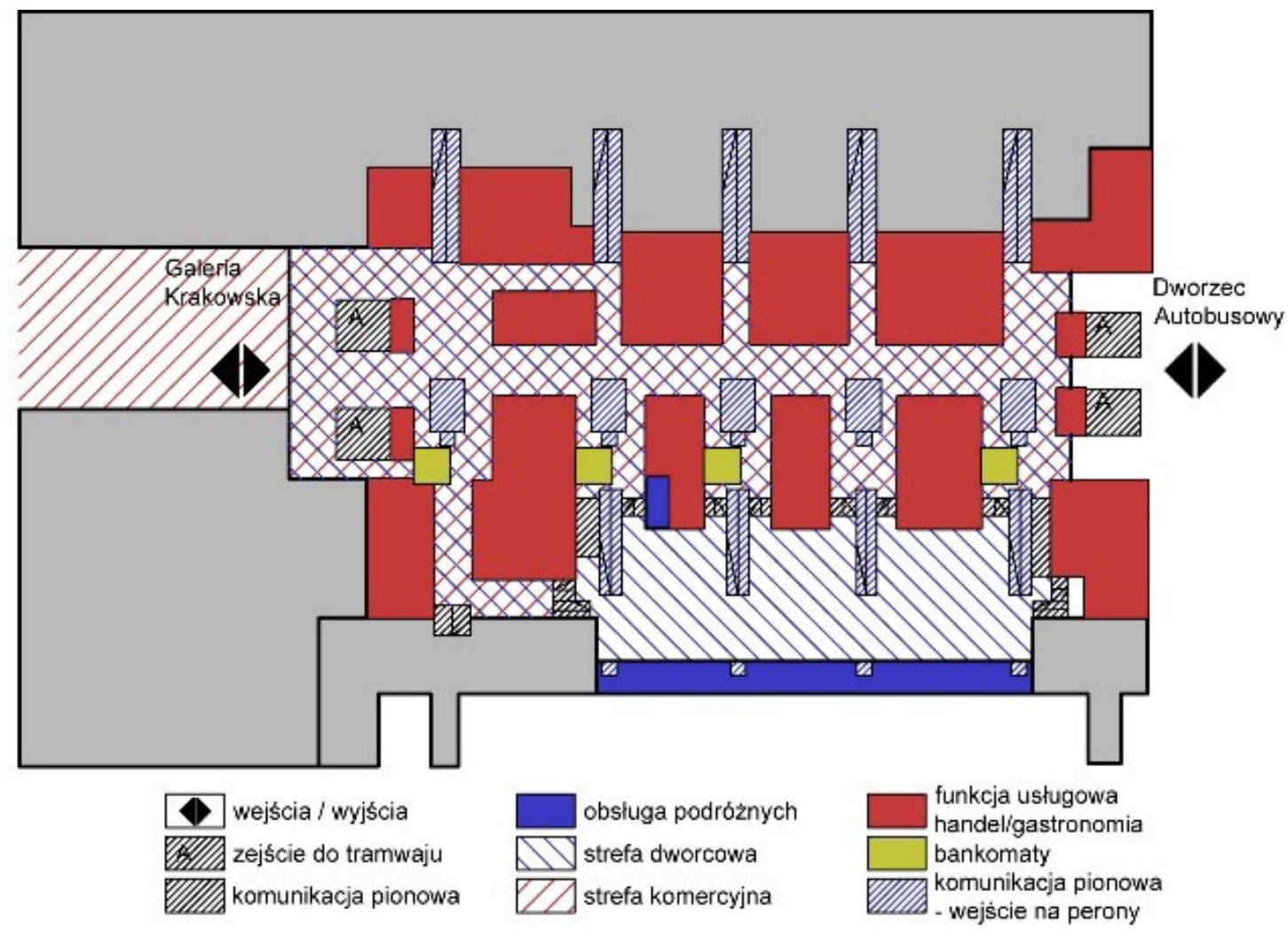

Ryc. 3. Ryc. 3. Dworzec Kraków Główny, zatarta granica pomiędzy dwiema funkcjami; Schemat obiektu, źródło: http://bi.gazeta. pl/im/b5/d0/eb/z15454389Q,Plan-dworca-w-Krakowie.jpg (dostęp: 21.11.2016 r.), oprac. W. Jabłoński;

II. 3. Main Railway Station, Kraków, blurred boundaries between two functions; scheme of the railway station, own study by W. Jabłoński based on http://bi.gazeta.pl/im/b5/d0/eb/z15454389Q,Plan-dworca-w-Krakowie.jpg (access: 21.11 .2016 r.)

Wrocław Główny stanowi przykład, w którym w jednoprzestrzennym holu dworcowym również wprowadzono funkcje komercyjne. Sama przestrzeń dotycząca podróży jest dominująca nad lokalami gastronomicznymi i handlowymi. Tu również zastosowane jest zróżnicowanie wysokości, jednak głównym poziomem, na którym 
znajdują się podstawowe funkcje dworca, jest przyziemie, a więc wejście do obiektu przez plac dworcowy. Lokale gastronomiczne znajdują się na tarasach w przestrzeniach dawnych sieni dworca ${ }^{3}$ oraz dawnych peronów.

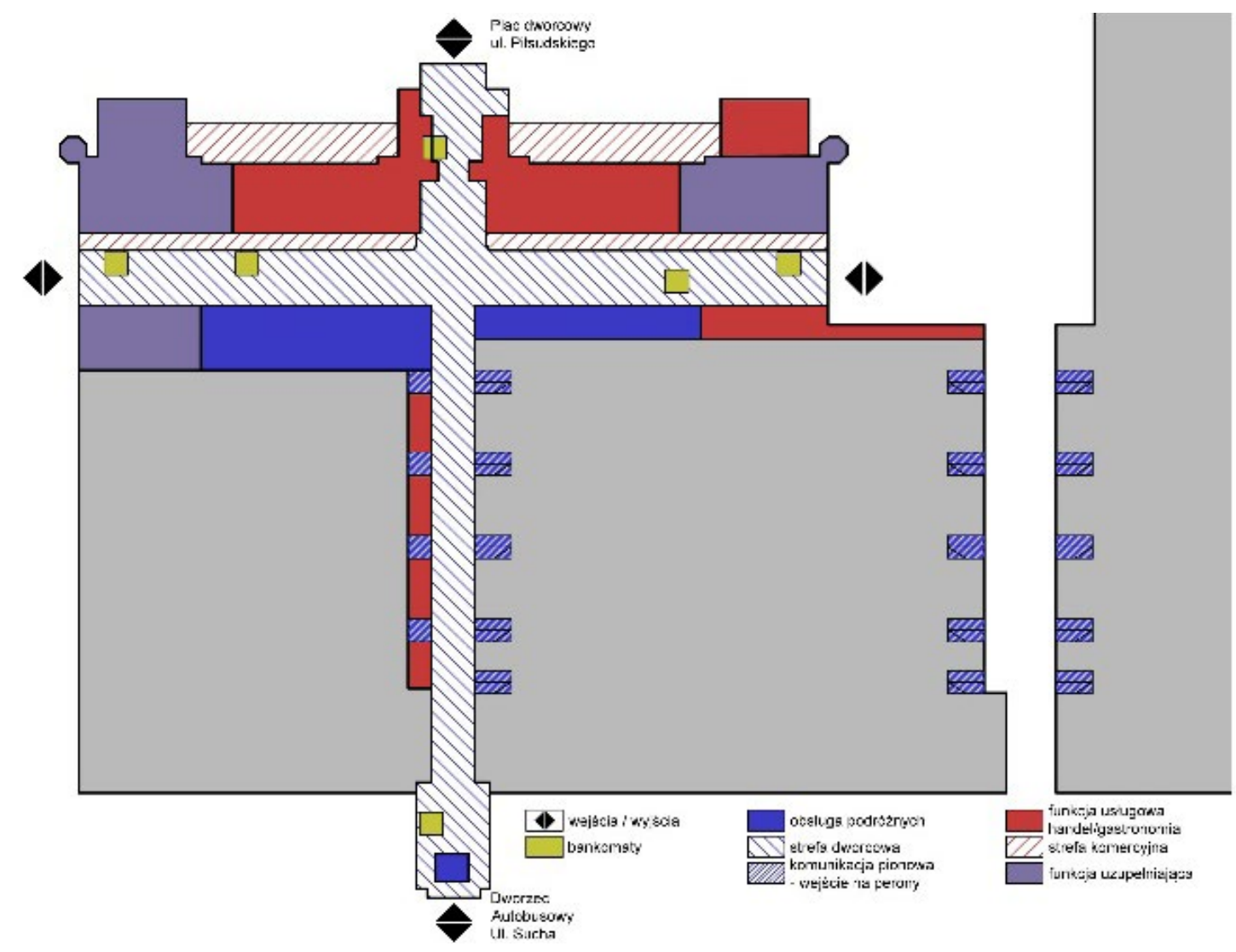

Ryc. 4. Ryc. 4. Dworzec Wrocław Główny - schemat obiektu, źródło: pkpsa.pl/dla-pasazera/dworce-opisy/mapy_dworce_wifi/ wroclaw_mapka_10.09.pdf (dostęp: 21.11.2016 r.), oprac. W. Jabłoński;

II. 4. Main Railway Station, Wrocław; scheme of the railway station, own study by W. Jabłoński based on pkpsa.pl/dla-pasazera/ dworce-opisy/mapy_dworce_wifi/wroclaw_mapka_10.09.pdf (access: 21.11.2016 r.);

Często spotykanym przypadkiem w obiektach użyteczności publicznej, a w szczególności centrach handlowych, jest wprowadzenie dodatkowym funkcji w ciągach komunikacji. W dynamicznym otoczeniu ciągłego ruchu użytkowników dodatkowe elementy mogą stanowić przeszkodę użytkową, utrudniać płynność ruchu, a w przypadku elementów ruchomych, stwarzać zagrożenia dla czytelności przestrzeni. Przykładem tego typu rozwiązań są otwarte sale restauracyjne w centrach handlowych. Cel, jakim jest różnorodna oferta wielu lokali, zaburza orientację w przestrzeni, a ruchome wyposażenie może stanowić bezpośrednią przeszkodę na drodze. Ponadto bardzo często forma architektoniczna elementów budowlanych, takich jak słupy, zawęża lub dzieli w sposób niekorzystny ciąg komunikacyjny, który dodatkowo zaburzony jest formami małej architektury, takimi jak ławki i tablice informacyjne, często będącymi bardzo istotnymi elementami danej przestrzeni. 
a)

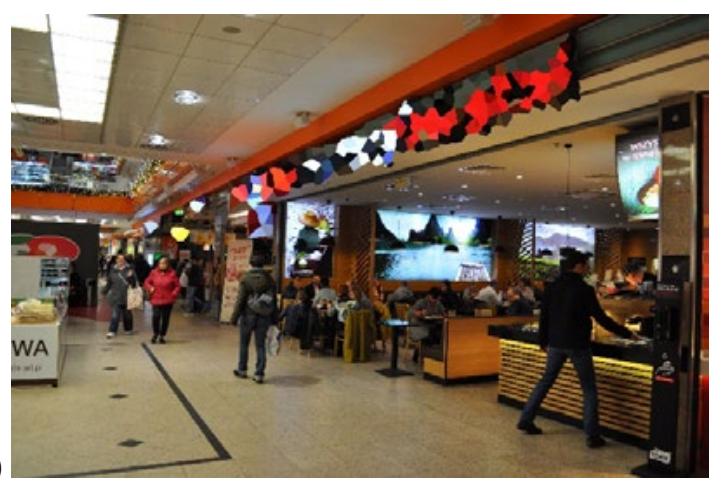

b)

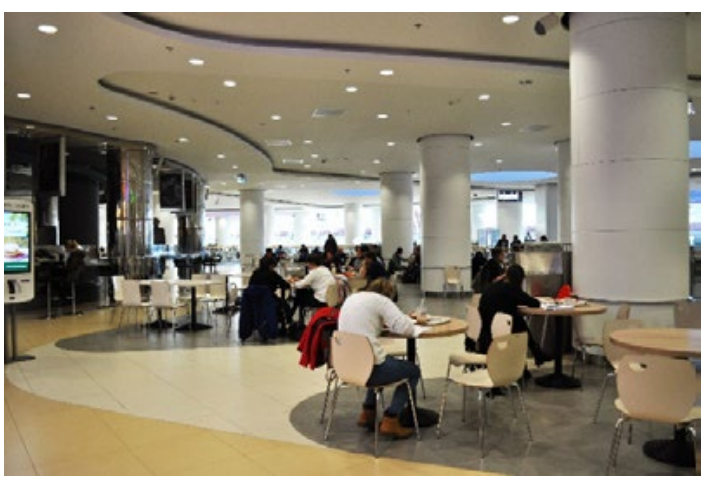

Ryc. 5. Restauracje w centrach handlowych: A - Galeria Dominikańska, przestrzenie restauracyjne jako oddzielne lokale nieznajdujące się w przestrzeni komunikacji; B - Pasaż Grunwaldzki, sala restauracyjna w jednej przestrzeni z komunikacją; fot. W. Jabłoński

II. 5. Restaurants in shopping malls: A - Galeria Dominikańska, restaurants as locals separated from communications areas; B - Pasaż Grunwaldzki, restaurant area as singular space with communication; phot. W. Jabłoński

\section{Obiekt - rozwiązania architektoniczno-budowlane i elementy budowlane}

Istotnym elementem stanowiącym barierę dla osób z dysfunkcją wzroku są poszczególne rozwiązania budowlane, takie jak elementy funkcjonalne, -, -materiałowe czy kolorystyczne. Jednym z podstawowych problemów przy kształtowaniu przestrzeni jest wprowadzenie elementów architektonicznych na wysokości zagrażającej bezpieczeństwu fizycznemu- będących niemożliwymi do odczytania za pomocą laski dla niewidomych lub, w przypadku osób słabowidzących, nie wyróżniających się w przestrzeni. Należy mieć świadomość, że odczytywanie przestrzeni za pomocą laski obejmuje ograniczony obszar wokół osoby niewidzącej, która wynosi około 90 centymetrów szerokości i umożliwia odczytanie przestrzeni na ograniczonej wysokości. Kolejnym przykładem tego typu elementów występujących w przestrzeni są schody. Bardzo często niezabudowane miejsca pod schodami stwarzają zagrożenie uderzenia w nie głową. W takim wypadku przestrzenie tego typu należy oznaczyć pasem ostrzegawczym na posadzce oraz żółto-czarnym pasem na elemencie zagrażającym bezpieczeństwu (il. 7).

a)



b)

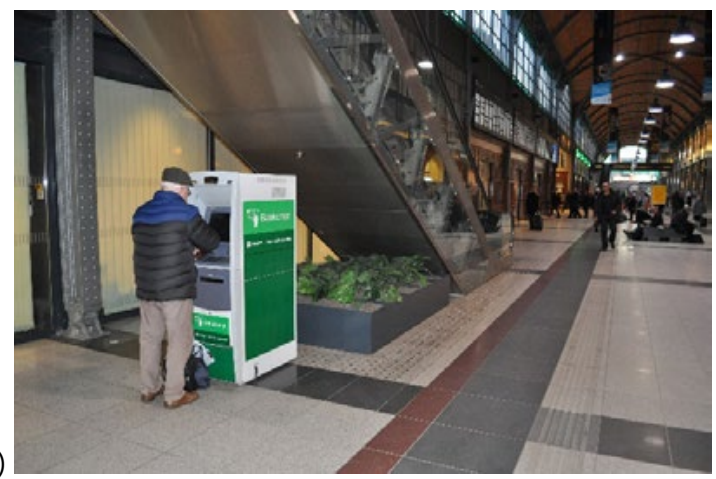


c)

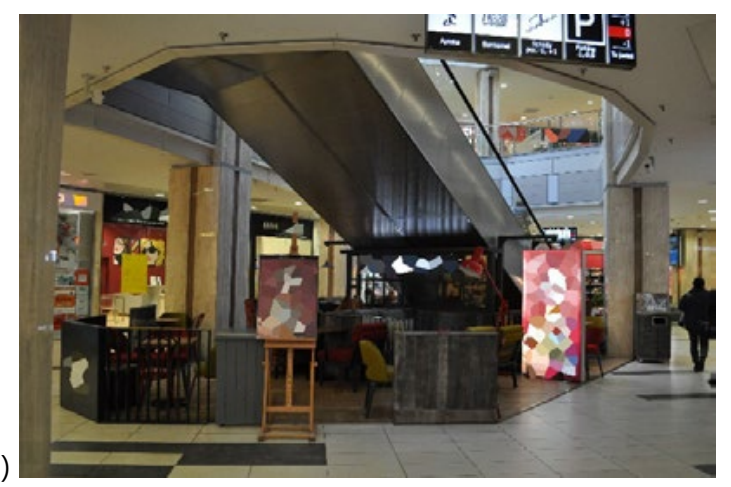

d)

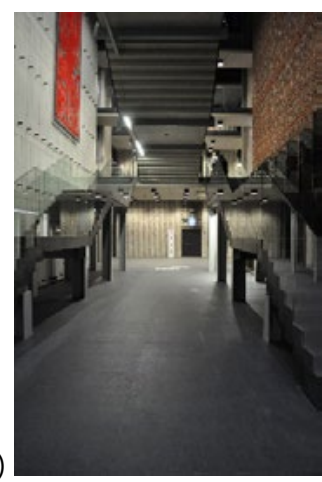

Ryc. 6. Schody w obiektach użyteczności publicznej: A - Politechnika Wrocławska C-13, niezbudowana przestrzeń pod biegami schodów, wprowadzony żółto-czarny pas ostrzegawczy na policzkach schodów; B - Dworzec Wrocław Główny - przestrzeń pod niezabudowanym biegiem oznaczona polem ostrzegawczych, dodatkowo wprowadzone elementy małej architektury; C - Pasaż Grunwaldzki, Wrocław, przestrzeń pod biegami schodów wykorzystane na przestrzeń kawiarnianą; D - Centrum Spotkania Kultur, Lublin, niezabezpieczone przestrzenie pod niezabudowanymi schodami; fot. W. Jabłoński;

Ryc. 6. Stairs: A - Wrocław University of Science and Technology C-13, free space under the staircase, warning tape of black and yellow stripes; B - Main Railway Station, Wrocław - area under the stiarcase marked with warning fields and occupied by small architecture; C - Pasaż Grunwaldzki, Wrocław, coffee shop under the staircase ; D - Centrum Spotkania Kultur, Lublin, areas under the stairs with no warnings or other functions; phot. W. Jabłoński

Współczesna architektura i jej trendy niosą za sobą wiele zagrożeń względem osób z dysfunkcjami wzroku. Jednym z podstawowych problemów jest tworzenie przestrzeni jednorodnych wizualnie i materiałowo.

Polskie przepisy budowlane regulują tylko dwa aspekty, które mogą być ułatwieniem dla osób niepełnosprawnych wzrokowo: zmianę kolorystyczną pierwszego i ostatniego stopnia w biegu schodów oraz stosowanie oznaczeń wizualnych na przeszklonych taflach drzwi ${ }^{4}$. Jednorodność kolorów i brak kontrastów pomiędzy elementami budowlanymi daje nieczytelny obraz przestrzeni. Zaciera się granica między ścianą a posadzką czy stolarką lub elementami funkcjonalnymi takimi jak ścieżka rowerowa a chodnik, bądź płyta manewrowa na dworcu autobusowym a peron. Wpływa to bezpośrednio na bezpieczeństwo użytkowania przestrzeni i komfort psychiczny osób niepełnosprawnych. Przy projektowaniu należy pamiętać o stosowaniu kontrastów kolorystycznych o wartości minimalnej 30\%, a zalecanej 70\% ${ }^{5}$. Jednym z najbardziej charakterystycznych zestawień kolorystycznych jest żółty-czarny (wartość kontrastu 92\%), jako że kolor żółty jest ostatnim kolorem, którego możliwość widzenia się traci.

Różnice kolorystyczne i materiałowe mogą ponadto wskazywać na różnice funkcjonalne w poszczególnych obiektach lub wskazywać na zmiany otoczenia. Zastosowanie miękkiej faktury może wskazywać na przestrzeń o charakterze wypoczynkowym, różnica materiałów na chodniku może sugerować bliskość elewacji budynku lub miejsc postojowych.

4 Rozporzadzenie Ministra Infrastruktury z dnia 12 kwietnia 2002 r. w sprawie warunków technicznych, jakim powinny odpowiadać budynki i ich usytuowanie, Dz. U. $2002 \mathrm{nr} 75$ poz. 690

5 Wytyczne ADA\&ADAAG, źródło: Wysocki M., 2010, Projektowanie otoczenia dla osób niewidomych. Pozawzrokowa percepcja przestrzeni, Gdańsk, s. 104-105 
a)



b)
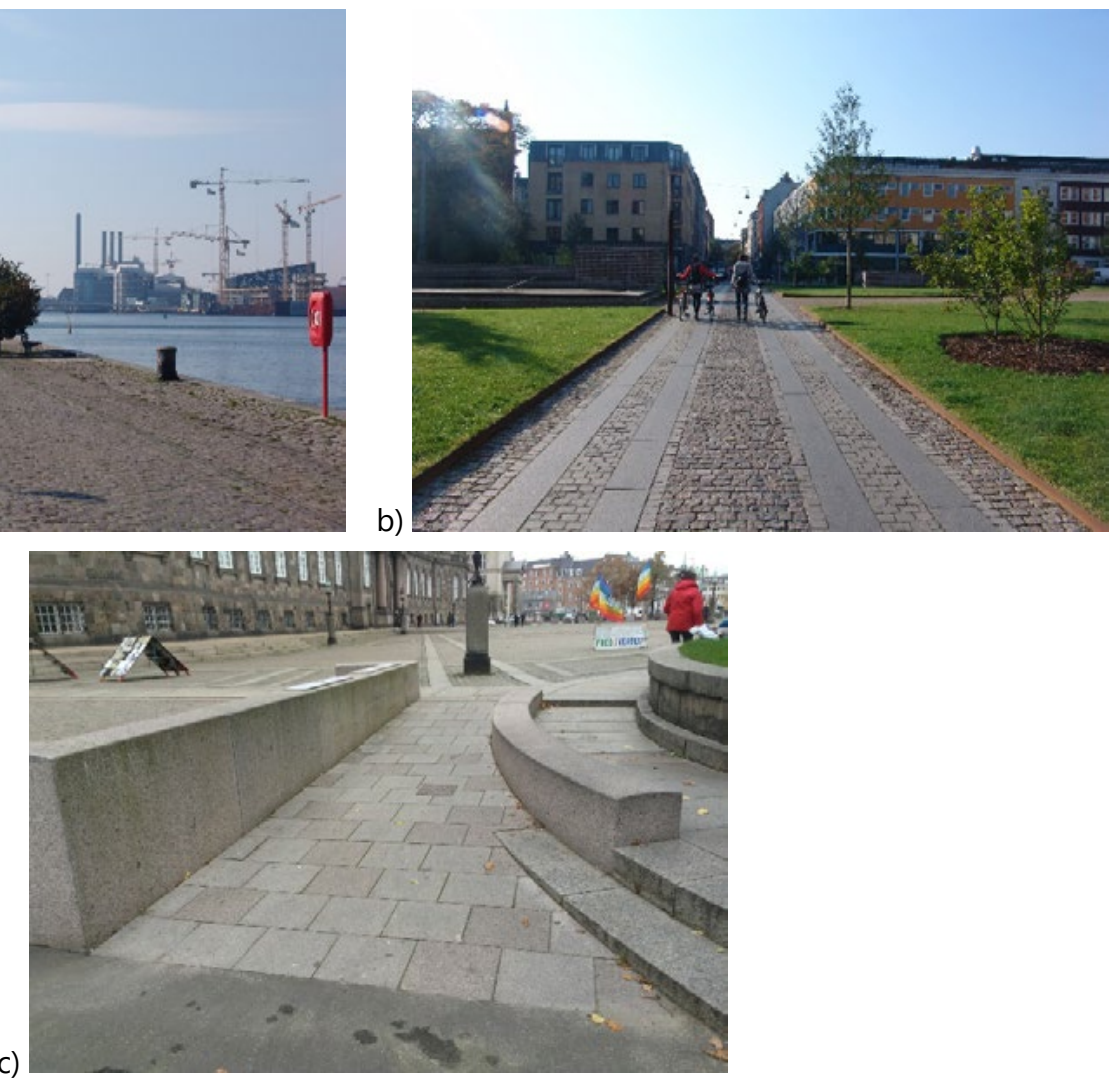

Ryc. 7. Ryc. 7. Zróżnicowanie materiału: A,B - Kopenhaga, zróżnicowanie faktury nawierzchni oraz wielkości elementów tworzy pasy naprowadzające; $C$ - Kopenhaga - różnica w materiałach wskazuje na poszczególne elementy terenu, pasy płyt kamiennych wskazują na najważniejsze kierunki w przestrzeni; fot. E. Przesmycka;

Ryc. 7. Difference in material: A, B - Copenhagen, difference of texture in pavement and different sizes of elements creating guidance lane; C - Copenhagen - differences in materials point out different elements in the terrain, strips of stone slabs indicate the most important directions; phot. E. Przesmycka

Innym zagrożeniem dla osób z dysfunkcją wzroku jest stosowanie dużej ilości nieoznaczonych przeszkleń zarówno w formie ścian przeszklonych, drzwi, jak i balustrad. Szkło, stanowiąc element dzielący przestrzeń fizycznie, w przypadku osób słabowidzących jest elementem nie dającym się wyróżnić wizualnie jako bariera fizyczna.

a)



b)

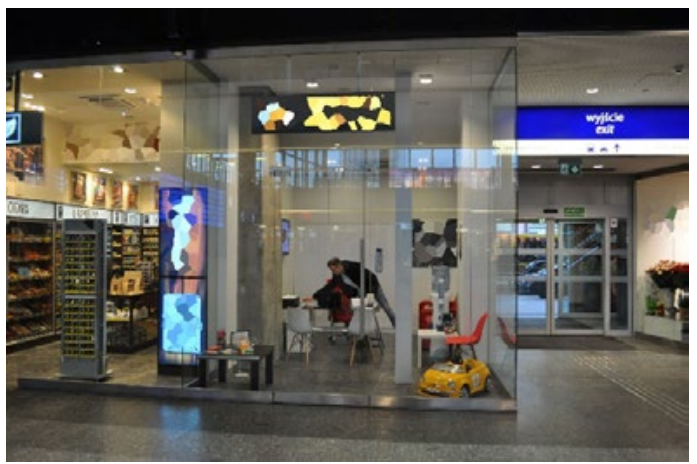


C)

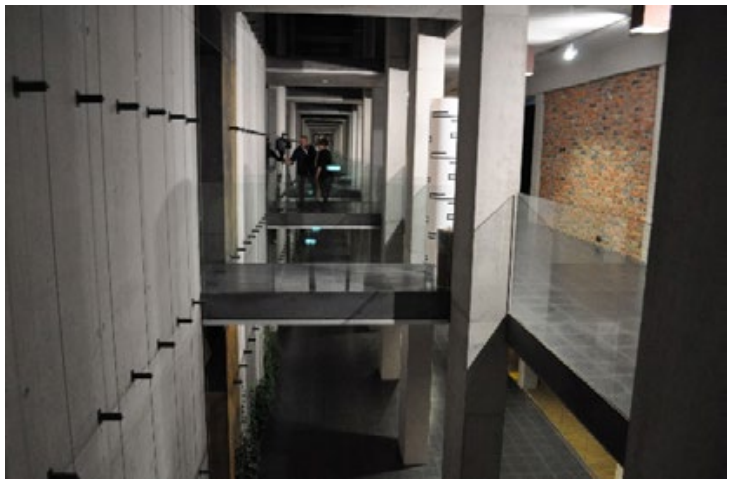

d)

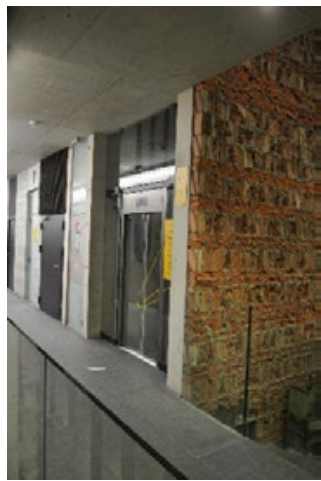

Ryc. 8. Ryc. 8. Szklane elementy w przestrzeniach użyteczności publicznej: A - Dworzec Warszawa Centralna, witryna wejściowa, oznaczenia pasem na szklanych drzwiach wejściowych do obiektu; B - Dworzec Warszawa Centralna, szklane przegrody bez oznaczenia; C - Centrum Spotkania Kultur, Lublin, szklane barierki pozbawione detalu nie wyróżniają się i są słabo widoczne w przestrzeni; D - Centrum Spotkania Kultur, Lublin, szklana obudowa szybu windowego; fot. W. Jabłoński

Ryc. 8. Glass elements in public utility buildings: A - Central Railway Station, Warsaw, entrance, glass door marked with stripes ; B - Central Railway Station, Warsaw, glass walls and doors with no safety marks; C - Centrum Spotkania Kultur, Lublin, glass balustrades with no details and railings can be hardly recognizable by visually impaired people; D - Centrum Spotkania Kultur, Lublin, glass partition of the elevator; phot. W. Jabłoński

Tworzenie środowiska dla osób z dysfunkcjami wzroku to także zapewnienie właściwych parametrów akustycznych. W kontekście środowiska miejskiego oznacza to izolację od zewnętrznych bodźców akustycznych takich jak ruch miejski, zaburzający informacje docierające do odbiorcy lub wymagające od niego wzmożonego skupienia na odbieraniu bodźców istotnych do funkcjonowania w obiekcie. Problematycznym wydaje się również trend we współczesnej architekturze polegający na tworzeniu surowych wnętrz z twardych materiałów takich jak beton, pozbawionych innych elementów wystroju. Minimalistyczne wnętrza niosą zagrożenie związane z nadmiernym pogłosem. Należy jednak pamiętać, że całkowita eliminacja-odbicia fal akustycznych, usuwa jednocześnie informacje dla osób niewidomych dotyczące parametrów przestrzeni.

\section{Tyflografika}

Poza ogólnymi warunkami wpływającymi na komfort użytkowania przestrzeni i wspomagającymi odbiór informacji ze środowiska, należy zapewnić odpowiednie źródła informacji dotyczących bardziej szczegółowych aspektów użytkowych. O ile osoby widzące nie mają problemów z odczytaniem przebiegu ciągów komunikacyjnych, poszczególnych funkcji czy informacji pisanych, o tyle dla osób niewidomych i słabowidzących należy zapewnić dodatkowe elementy wspomagające. Do dyspozycji pozostaje wiele rozwiązań tyflograficznych mający ułatwić funkcjonowanie w obiekcie. Jednym z podstawowych są wytłaczane tabliczki montowane przy ladach lub na pochwytach balustrad z informacjami przekazanymi za pomocą alfabetu Braille'a.

a)

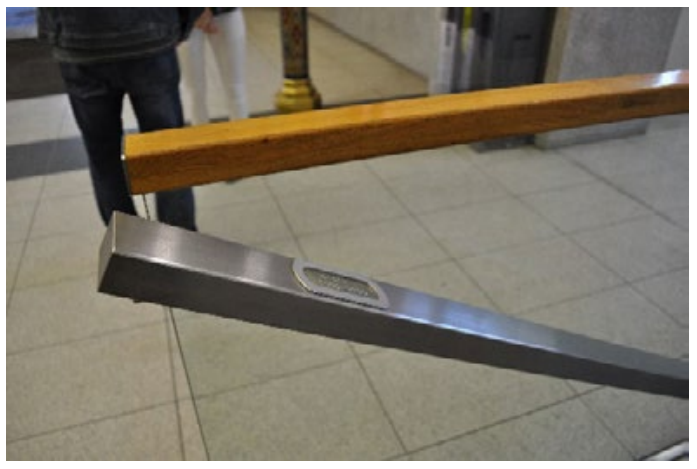

b)

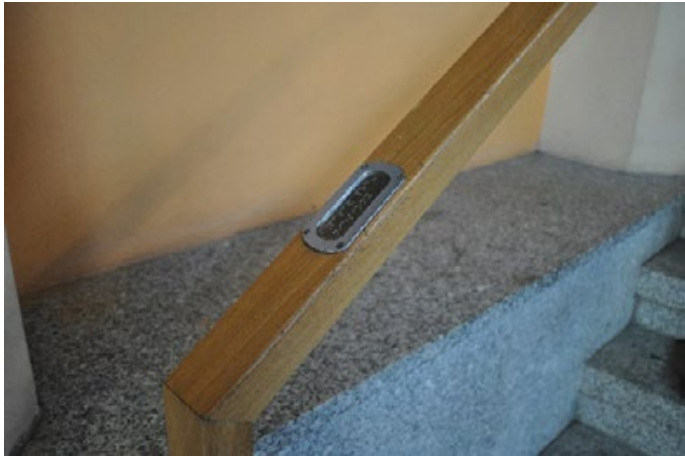




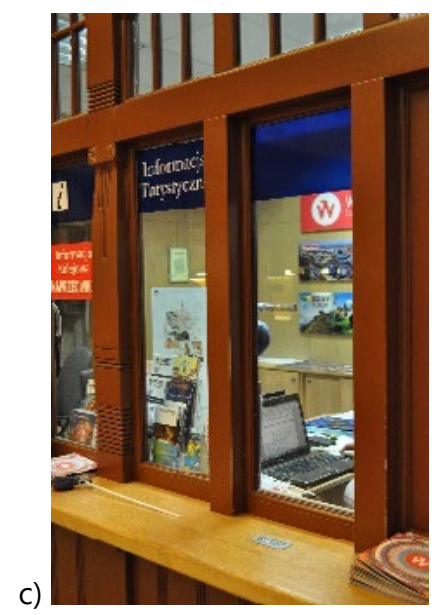

Ryc. 9. Ryc. 9. Dworzec Wrocław Główny - tabliczki z informacjami w Braille’u; fot. W. Jabłoński II. 9. Main Railway Station, Wrocław -information panel in Braille; phot. W. Jabłoński

Stosowane w przestrzeni piktogramy, jako proste znaki graficzne, mają za zadanie w sposób możliwie mało inwazyjny informować o poszczególnych funkcjach i ich lokalizacji w obiekcie. W celu poprawy ich odbioru dla osób z dysfunkcjami wzroku należy stosować zasadę kontrastu. Jednym z najpopularniejszych zestawień są niebieskie znaki na białym tle lub zestawienie żółtego i czarnego.


Wyjscie/
Exit

a)

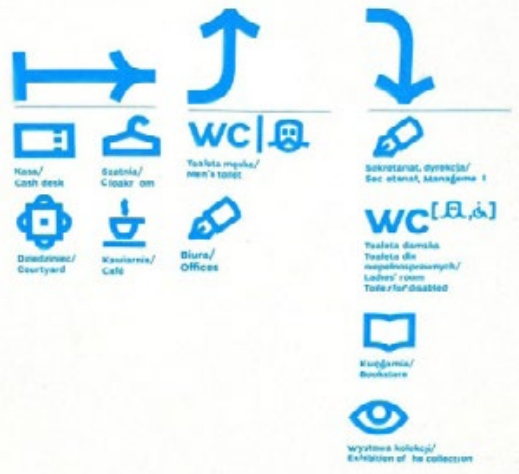

b)

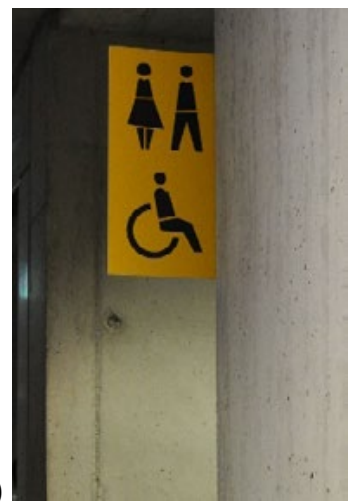

Ryc. 10. Ryc. 10. Piktogramy: A - Pawilon Czterech Kopuł, Wrocław, kontrastowe, niebieskie piktogramy na białym tle; B - Centrum Spotkania Kultur, Lublin, kontrastowe, czarne znaki graficzne na żółtym tle; fot. W. Jabłoński

Ryc. 10. Pictograms: A - The Four Domes Pavilon, Wrocław, blue icons contrast with white background; B - Centrum Spotkania Kultur, Lublin, black icons contrast on yellow background; phot. W. Jabłoński

Podstawowym rozwiązaniem mającym na celu ułatwienie orientacji w przestrzeni jest stosowanie ścieżek dotykowych wraz z pasami ostrzegawczymi. Liniowe żłobienie lub wypukłości w posadzce mają za zadanie wskazywać najważniejsze połączenia pomiędzy poszczególnymi funkcjami. W przypadku zmiany kierunku, końca ścieżki lub zagrożenia w przestrzeni takiego jak jezdnia, koniec peronu, schody czy obniżony element budowlany stosuje się pola ostrzegawcze w postaci wypukłych krążków w posadzce. System ten jest łatwo wyczuwalny za pomocą dotyku oraz laski. 
a)

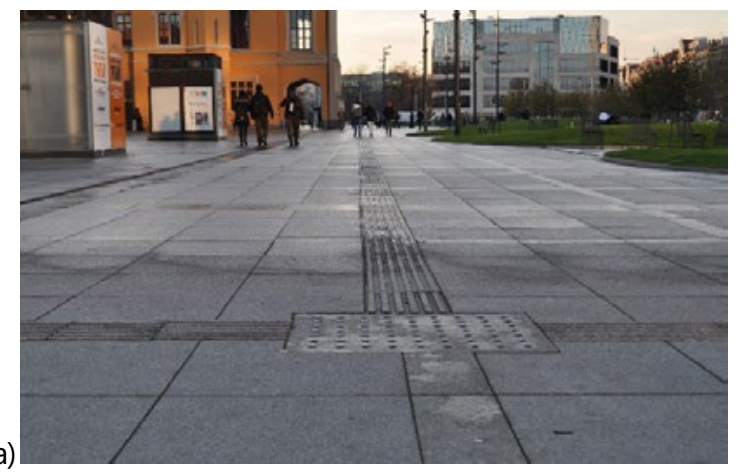

b)
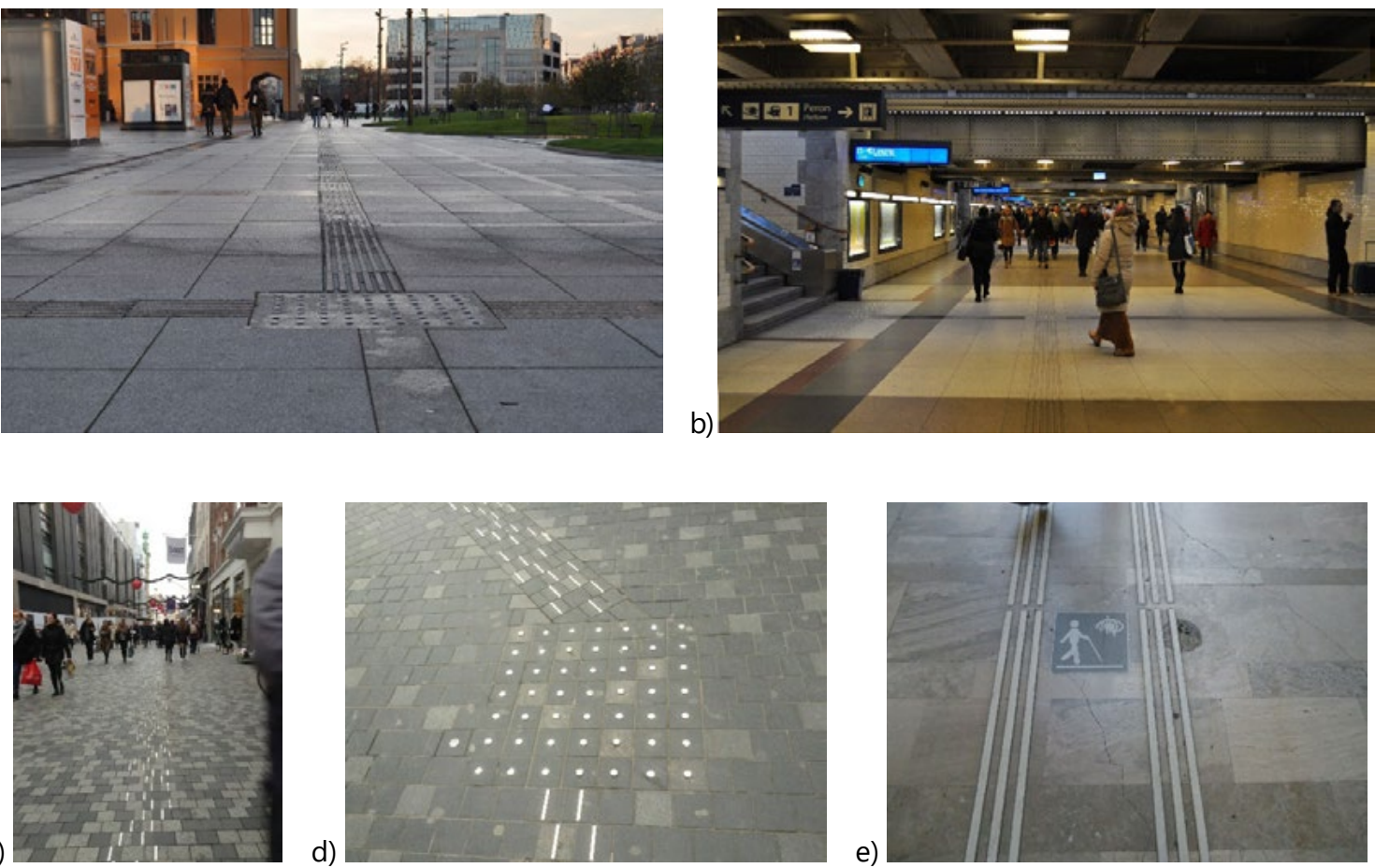

d)

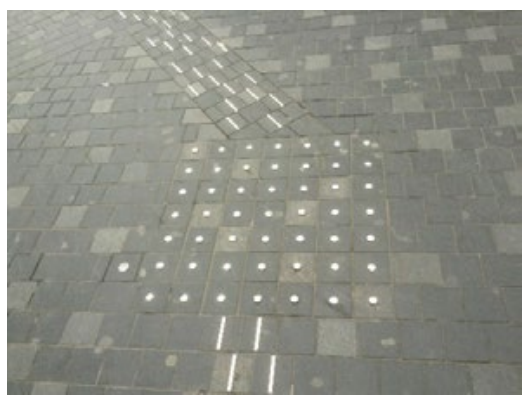

e)

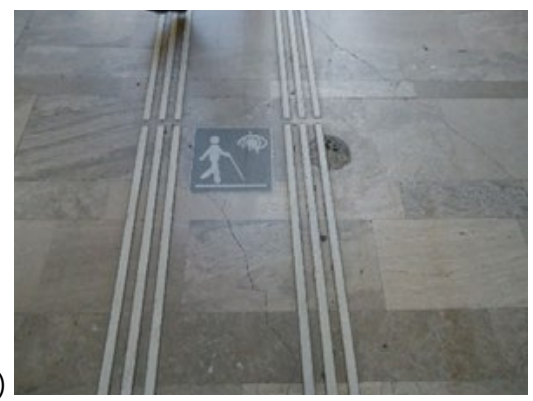

Ryc. 11. Ryc. 11. Ścieżki dotykowe i pola ostrzegawcze; A - Plac dworcowy, Wrocław; B - Dworzec Wrocław Główny, tunel pod peronami; fot. W. Jabłoński; C - Kopenhaga, ścieżka dotykowa w formie pojedynczych pasków w drobnej kostce brukowej, nawiązuje do nawierzchni i nadaje indywidualny charakter ścieżki wpasowujący się w estetykę przestrzeni; D - Kopenhaga, pole ostrzegawcze ścieżki dotykowej na il. 11 C również wpasowujące się w charakter pasów naprowadzających; D - Paryż ścieżka dotykowa; fot. E. Przesmycka

Ryc. 11. Tactile paths and tactile warning areas; A - the station square, Wrocław; B - Main Railway Station, Wrocław, tunnel under the platforms; phot. W. Jabłoński; C - Copenhagen, tactile path in the form of small, single lines in a small paving stone refers to the surface and gives an individual character on the lane matching to aesthetic of the space; D - Copenhagen, tactile warning area matching of the tactile lane on il. $11 \mathrm{C}$ matching the character of tactile path; E - Paris, tactile path; phot. E.Przesmycka

Dopełnieniem ścieżek dotykowych w obiektach użyteczności publicznej powinny być mapy dotykowe sytuowane przy wejściu do budynku lub w miejscu łatwym do odnalezienia. Powinny one mieć legendę oraz być zorganizowane w sposób czytelny i regularny, żeby w łatwy sposób móc odnaleźć poszukiwane informacje. Gdy są chaotycznie zorganizowane, stwarzają zagrożenie pominięcia poszczególnych informacji. Przy mapach tyflograficznych powinny znajdować się również mapy dla osób widzących, żeby obie grupy społeczne mogły w równym stopniu odczytać plan. W dobie współczesnych technologii takich jak frezowanie, drukowanie na drukarkach 3D czy wycinanie laserowe w różnych materiałach, mapy dotykowe mogą stanowić nie tylko źródło informacji, ale również detal wykończeniowy wnętrza czy przestrzeni publicznej.

a)

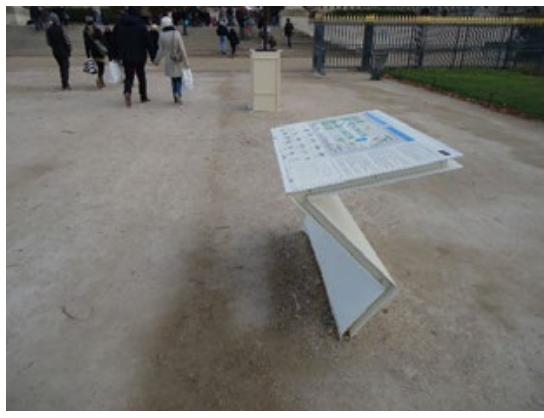

b)

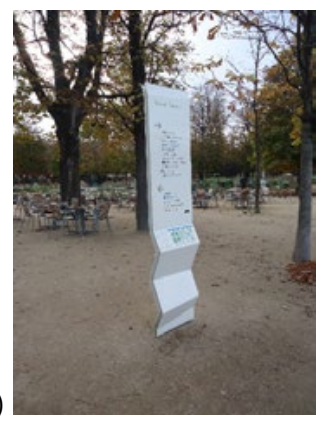

c)

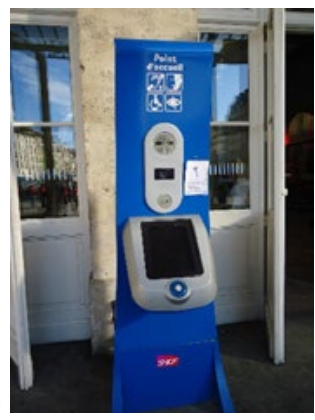


Ryc. 12. Ryc. 12. Mapy dotykowe; A, B - Paryż, mapy dotykowe w przestrzeni publicznej dostępne także dla osób poruszających się na wózku inwalidzkim, C - Paryż, punkt pomocy dla osób niepełnosprawnych; fot. E. Przesmycka

Ryc. 12. Tactile maps; A, B - Paris, tactile maps in public space available for people on wheelchair; C - Paris, point of assistance for disabled people; phot. E. Przesmycka

Wprowadzenie układów przestrzennych oraz elementów funkcjonalnych w obiekcie nie gwarantuje jeszcze pełnej dostępności dla osób niepełnosprawnych. Często bariery w obiektach użyteczności publicznej spowodowane są niewłaściwym zarządzeniem. Na ścieżkach dotykowych sytuowane są dodatkowe elementy takie jak mała architektura lub inne przenośne, tymczasowe formy. Brakuje również map dotykowych, które są podstawowym źródłem informacji o przebiegu poszczególnych ścieżek.
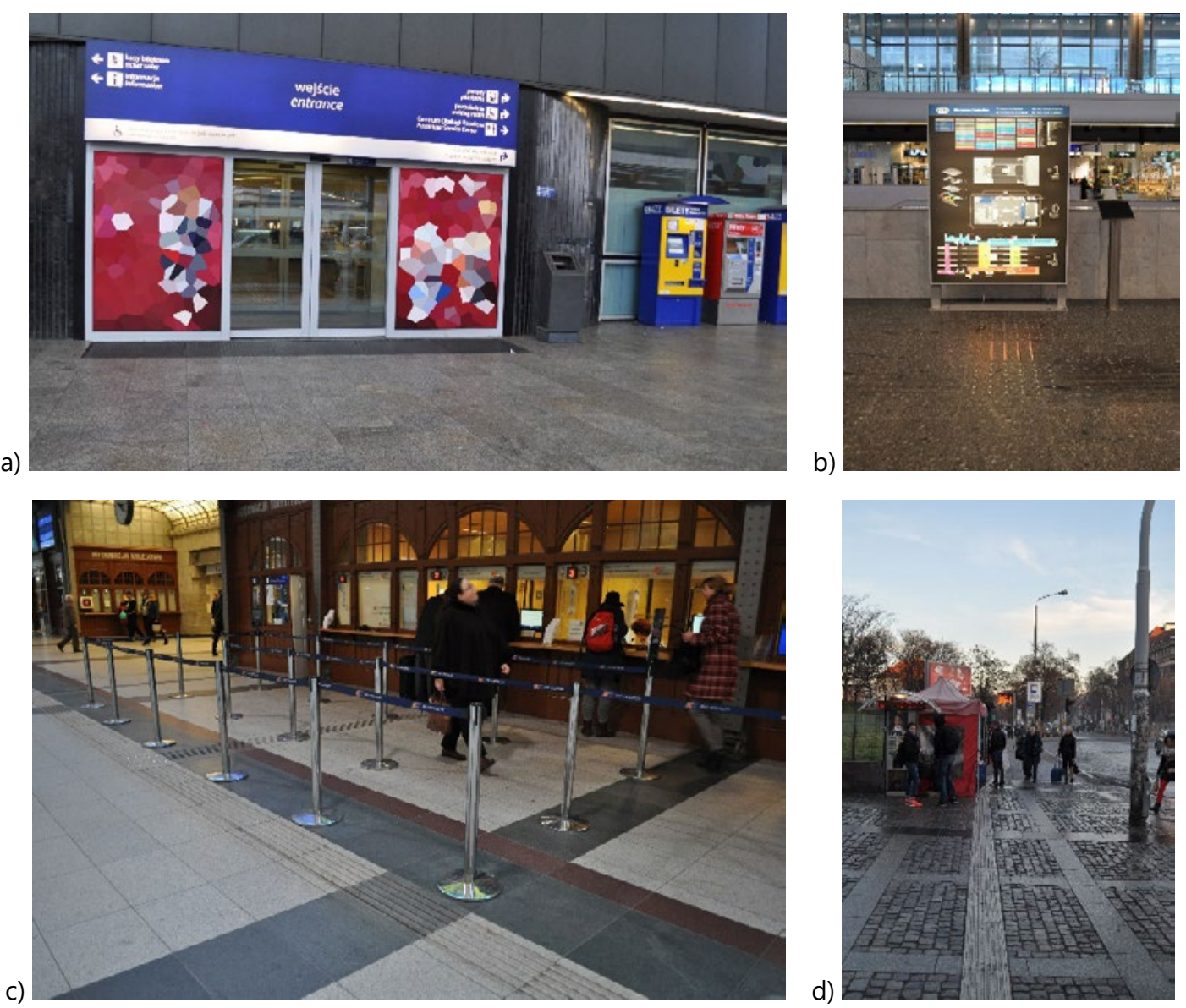

Ryc. 13. Ryc. 13. Błędy w przestrzeni pomimo zastosowania technik tyflograficznych; A - Dworzec Warszawa Centralna, brak ścieżek dotykowych na zewnątrz obiektu w otoczeniu przystanków autobusowych; B - Dworzec Warszawa Centralna, brak mapy dotykowej (stan: 27.11.2016 r.); C - Dworzec Wrocław Główny, ścieżka dotykowa prowadząca do kas biletowych przecięta taśmą do formowania kolejki; D - Dworzec Wrocław Główny, stoisko z książkami przy ścieżce dotykowej; fot. W. Jabłoński

Ryc 13. Barriers in space despite use of tyflographic technologies; A - Central Railway Station, Warsaw, absence of tactile paths outside the station in the proximity of bus station; B - Central Railway Station, Warsaw, absence of tactile map (state: 27.11.2016 r.); C - Main Railway Station, Wrocław, tactile path leading to the ticket office is crossed by the tape forming the queue; D - Main Railway Station, Wrocław, book stall on the tactile path; phot. W. Jabłoński

Ponadto wiele urządzeń w przestrzeniach publicznych dostosowana jest niemal wyłącznie dla osób widzących. Bardzo atrakcyjne z punktu widzenia technologii ekrany dotykowe w bankomatach, biletomatach czy windach są kolejną barierą dla osób z dysfunkcją wzroku. Pomimo stosowania nakładek z alfabetem Braille'a w urządzeniach, są one niepraktyczne, ponieważ odczytanie informacji wiąże się z włączeniem danej funkcji. 
a)


Ryc. 14. Ryc.14. Bariery dla osób z dysfunkcją wzroku - ekrany dotykowe; A - Promenady Wrocławskie, dotykowy panel windy z naklejkami z alfabetem Braille’a; B - Dworzec Wrocław Główny, biletomat z ekranem dotykowym; fot. W. Jabłoński Ryc 14. Barriers for visually impaired people - touch screens; A - Promenady Wrocławskie, touch panel in the elevator with stickers with Braille alphabet; B - Main Railway Station, Wrocław, ticket machine with touch screen; phot. W. Jabłoński

\section{Podsumowanie}

Projektowanie uniwersalne to projektowanie dla wszystkich bez dyskryminacji jakiejkolwiek grupy społecznej. Projektant winien traktować to nie tylko jako wyzwanie, ale jako obowiązek, zwłaszcza w kontekście obiektów użyteczności publicznej oraz przestrzeni publicznych i półpublicznych. Projektowanie uniwersalne może wydawać się tworzeniem jednorodnej architektury czy urbanistyki, charakteryzującym się powtarzalnością rozwiązań i pozbawionym cech indywidualności. Należy jednak pamiętać, że użyteczność publiczna i związane z nią obszary to środowisko fizyczne życia każdego człowieka. Można - zauważyć, że pewne elementy projektowania dla osób niepełnosprawnych mogą stanowić ułatwienie również dla osób zdrowych, dla których środowisko fizyczne wydaje się proste i oczywiste ze względu na odpowiednią percepcję wzrokową świata.

Poprzez różne rozwiązania wskazane w pracy, można stwierdzić, że uniwersalność obiektu zaczyna się już na etapie koncepcji funkcjonalno-przestrzennej i nie kończy się na fazie wykonawczej, ale dotyczy również dalszego życia obiektu - jego zarządzania i późniejszych zmian architektonicznych. W tym kontekście projektowanie uniwersalne i nastawienie względem osób niepełnosprawnych to problem nie tylko braku świadomości u projektantów, ale także u osób zarządzających przestrzeniami publicznymi.

\section{Bibliografia}

[1] Harasimowicz J., 1997, Atlas Architektury Wrocławia, tom I, Wroctaw

[2] Kowalski K., Starzyńska D. (red.), Projektowanie bez barier - wytyczne, Warszawa

[3] Leszczyńska A., 2016, Do czego potrzebne jest projektowanie uniwersalne i adaptacja przestrzeni, [w:] Projektowanie i adaptacja przestrzeni publicznej do potrzeb osób niewidomych i słabowidzących, Polski Związek Niewidomych, Warszawa

[4] Leszczyńska A., Fabisiak A., 2016, Wskazówki do projektowania i adaptacji środowiska fizycznego do potrzeb osób niewidomych i słabowidzących, [w:] Projektowanie i adaptacja przestrzeni publicznej do potrzeb osób niewidomych i słabowidzących, Polski Związek Niewidomych, Warszawa

[5] Poliński J., 2012, Oznaczenia dotykowe dla osób niewidomych i słabowidzących część I - dotykowe elementy ostrzegawcze, [w:] Problemy Kolejnictwa, zeszyt 157

[6] Poliński J., 2013, Oznaczenia dotykowe dla osób niewidomych i słabowidzących część II - ścieżki dotykowe, [w:] Problemy Kolejnictwa, zeszyt 158 
[7] Poliński J., 2013, Oznaczenia dotykowe dla osób niewidomych i słabowidzących część III - Mapy dotykowe dworców kolejowych, [w:] Problemy Kolejnictwa, zeszyt 159

[8] Wysocki M., 2010, Projektowanie dla osób niewidomych. Pozawzrokowa percepcja przestrzeni, Gdańsk

\title{
Akty prawne:
}

[1] Główny Urząd Statystyczny, 2016, Stan zdrowia ludności Polski w 2014 r., Warszawa

[2] Deklaracja Madrycka, 2002, Europejski Kongres Osób Niepełnosprawnych, Madryt, 2002

[3] Rozporządzenie Ministra Infrastruktury z dnia 12 kwietnia 2002 r. w sprawie warunków technicznych, jakim powinny odpowiadać budynki i ich usytuowanie, Dz. U. 2002 nr 75 poz. 690 z późniejszymi zmianami

\section{Strony internetowe:}

[1] pkpsa.pl

[2] http://www.przedniaplatformatramwaju.pl

[3] http://bi.gazeta.pl

\section{The universality of space and public facilities in the context of people with sight dysfunction}

\begin{abstract}
A disability is very often associated with motor dysfunction, while visual, hearing or psychological dysfunctions are not rooted in the society awareness. Visual dysfunctions like motor disorders are a natural stage of the aging process. The lack of adaptation of public space and public facilities for the visually impaired or blind people is often a barrier for them. This article presents methods to help people with vision disabilities use public facilities and spaces. The article was divided into two parts. The first covers architectural and building solutions - pointing out the basic principles in architectural design and pointing to some of the mistakes emerging in buildings that may endanger the lives, safety or mental well-being of people with vision dysfunctions. These architectural solutions may influence the orientation in the space or reception of the incentives in architectural environment, but they are not always the detailed information system. The second part of the article is devoted to the typhlographic techniques used in public space as a form of small architecture or a detail - complement of architecture. These solutions give more accurate information such as the facility's communication system or utility information. Both parts of the article presents architectural and design solutions in order to enable visually impaired people efficient and safe use of space or building. They also point to the fact that design with regard to visually impaired people should begin at the functional and spatial concept, and include the detail and solutions in the executive project as well as proper spatial management.
\end{abstract}

Key words: Universal design, dysfunction of vision, public utility buildings 